\title{
Petrological confirmation of lithosphere thermally eroded by asthenospheric flow beneath the NE margin of the Tibetan plateau
}

\author{
MR. CHUTIAN SHU ${ }^{1}$, XIAOPING LONG ${ }^{2}$, STEPHEN F. \\ FOLEY $^{1}$ AND KAIZHANG YU ${ }^{3}$ \\ ${ }^{1}$ Macquarie University \\ ${ }^{2}$ Northwest University \\ ${ }^{3}$ China University of Geosciences \\ Presenting Author: chutian.shu@hdr.mq.edu.au
}

The India-Eurasia collision has resulted in northward uplift of the Tibet plateau since the Early Cenozoic, but whether this uplift is associated with the removal of lower lithosphere remains disputed. An increasing number of geophysical studies have been conducted at the northern margin of the Tibet plateau. Seismic anisotropy analysis revealed NWW-SEE asthenospheric flow ${ }^{[1]}$ and S-wave receiver functions revealed lithospheric steps (ca. $110 \mathrm{~km}$ in the south and 126-140 km in the north), which are interpreted as evidence for lithosphere erosion by asthenospheric flow $^{[2]}$. However, geophysics provides only a snapshot of the lithosphere today.

Independent petrological evidence comes from Miocene (16$20 \mathrm{Ma}^{[3]}$ ) xenolith-bearing melilitites in west Qinling at the northeastern margin of the Tibetan plateau. The melilitites display low $\mathrm{SiO}_{2}$ (38.1-41.9 wt.\%), high $\mathrm{MgO}$ (9.9-19.2 wt.\%) and variable alkalis (0.9-6.9 wt.\%) with $\mathrm{K}_{2} \mathrm{O} / \mathrm{Na}_{2} \mathrm{O}$ between 0.6 to 3.5. The high $\mathrm{K}_{2} \mathrm{O}$ content, $(\mathrm{La} / \mathrm{Yb})_{\mathrm{N}}(34-55)$ and $\left({ }^{187} \mathrm{Os} /{ }^{188} \mathrm{Os}\right)_{\mathrm{i}}(0.1486-0.5064)$ suggest a K-rich metasomatised source, which agrees with the occurrence of phlogopite-bearing xenoliths entrained in the melilitites ${ }^{[4]}$. Thermobarometry of silica-undersaturated melts ${ }^{[5]}$ shows that the primitive melilititic magma $(\mathrm{MgO}>12.5$ wt. $\%)$ was generated at $\approx 4.0 \mathrm{GPa}(\approx 130$ $\mathrm{km})$ and $\approx 1440^{\circ} \mathrm{C}$. This is consistent with the deepest xenolith (3.85 $\mathrm{GPa}^{[4]}$ ) entrained by the melilitites and experimental constraints for melilitite melt origin (ca. $4.0 \mathrm{GPa}^{[6]}$ ).

Given that (1) $1440^{\circ} \mathrm{C}$ is much higher than the geotherm constrained by the xenoliths, and equivalent to the adiabat temperature at $4.0 \mathrm{GPa}$; and (2) the present lithospheric thickness is $104 \pm 5 \mathrm{~km}$ in this area ${ }^{[2]}$, we interpret this as petrological confirmation of lithosphere erosion by asthenospheric flow starting from the Early Miocene. This explains the difference between the current lithosphere thickness and the depth of the melilitite source 20 myr ago, which was similar to the present thicker lithosphere to the north $\left(126-140 \mathrm{~km}^{[2]}\right)$.

[1] Zhang et al., 2011, EPSL 304, 103-112; [2] Xu et al., 2019, G-cubed 20, 993-894; [3] Liu et al., 2018, Geology 46, 1071030; [4] Su et al., 2010, Lithos 116, 111-128; [5] Sun et al., 2020, EPSL 550, 1-13; [6] Foley and Pintér, 2018, Magmas Under Pressure. 